\title{
Scientific Inquiry-Based Teaching Practices as Perceived by Science Teachers
}

\author{
Abdulaziz Aboud Mohammed Asiri* \\ Department of Curriculum and Instruction, Najran University, KSA \\ *Corresponding author: abdulaziz-asiri@hotmail.com
}

\begin{abstract}
The present study aimed to identify the nature of science teachers' practice of scientific inquiry-based teaching methods at public schools at Najran region in Saudi Arabia. A sample of (156) participants, among which were (84) male teachers and (72) female teachers, was randomly selected out of all teachers enrolled in teaching science at Najran region schools. A study instrument, i.e. questionnaire specific for scientific inquiry-based teaching methods, was applied to all participants. Findings showed that male science teachers usually practice scientific inquiry-based teaching methods once a month whereas responses of female science teachers indicated that they practice inquiry-based methods twice a month. Findings also revealed that most male teachers practice some of the inquiry aspects nearly once a week while female teachers do so twice a week. In light of these findings, the present study stressed the need to reconsider and revise the preparation programs for science teachers at all cycles of public education to meet the requirements of the new science curricula that consider inquiry as one of their main components.
\end{abstract}

Keywords: scientific inquiry, inquiry-based teaching methods, scientific inquiry components, science teachers and nature of teaching practice

Cite This Article: Abdulaziz Aboud Mohammed Asiri, "Scientific Inquiry-Based Teaching Practices as Perceived by Science Teachers.” American Journal of Educational Research, vol. 6, no. 4 (2018): 297-307. doi: 10.12691/education-6-4-2.

\section{Introduction}

Inquiry, as a method, is one of the oldest methods of learning and teaching. Socrates, the Greek philosopher, who lived between 470 \& 399 B.C., introduced the method of inquiry and used it in teaching. Inquiry implies the extraction of learner's knowledge and information via inquiry dialogue because each individual is seen unique with regard to his knowledge in various fields of life. Meanwhile, the individual's knowledge is incomplete, confusing or wrong and so the teacher's role is to correct or complete that knowledge and then add some new knowledge to it. Therefore, teaching according to inquiry model ensures learning to be learner-centered where the learner performs an effective role in the learning process and be responsible for it. The learner interacts with the teaching process actions, observes, compares, interprets and infers relationships that lead to the achievement of the educational goal. He, therefore, acquires a lot of capabilities and skills like self-confidence, observation accuracy, participation and teamwork, [1]. Furthermore, teaching, through the model of scientific inquiry, aims to explore the general scientific concepts and principles as well as the laws and specific theories related to the scientific content students learn by themselves. Thus, it becomes a means for scientific enlightenment and education of creative students. Scientific inquiry enables students to acquire the skills of conducting scientific experiments and solve problems by using their own abilities, [2]. That is, teaching using scientific inquiry makes learning realistic as it constructs contexts that are similar to those in reality, $[3,4]$.

Inquiry skills are of great interest in the scientific and educational communities. They are means for the continuity of the learning process where learners can have a deep understanding of a certain concept or phenomenon. They can also expand their knowledge of that concept or phenomenon and present their accurate scientific justifications and explanations. Inquiry-based science generates scientific culture, knowledge of scientific methods and terms, and understanding of concepts and positive attitudes, [5]. Through practicing inquiry, students ask questions that express their curiosity to explore a certain phenomenon. They can expand their knowledge, deepen it, and consequently look for research and inquiry via various knowledge resources. They also can gather and analyze information to answer their queries [6]. In addition, students can explain and support their answers by evidence and proofs. Gradual and continuous practice is highly demanded to improve and develop these skills among students. Therefore, students should be accustomed to practice such skills at early age moving from simplicity to complexity and from guidance to independence [7]. Thus, it is important to train students to use the scientific inquiry and its implied scientific thinking skills and learning processes besides it effective role in the development of learners' attitudes towards science, $[1,8]$. 
US National Science Standards attached great interest in the scientific inquiry and considered it as an important part of the teaching process. Transition from lecture and recitation-based traditional methods to scientific inquiry-based teaching methods is seen the core of the process of education reform $[9,10,11]$. Apart from the fact that these standards encourage the use of inquiry-based education in classrooms, these five main components were identified as the main components of scientific inquiry that should be included in teaching science:

- Asking questions about things, events and scientific phenomena around learners.

- Planning and implementing scientific inquiries.

- Using simple devices and tools for data collection.

- Using collected data to write convincing explanations about scientific objects, events and scientific phenomena.

- Communicating with others to deliver explanations and surveys.

\section{The Relationship among Inquiry, Academic Achievement and Positive Attitudes}

Inquiry refers to "The different methods by which scientists study the natural world and propose explanations depending on evidence resulted from their work" $[6,10]$. Inquiry is the use of knowledge, reasoning and critical thinking to develop one's scientific knowledge [12]. Besides, scientific inquiry complements the process of teaching science. Inquiry-based teaching can be used in teaching concepts and processes related to the nature of science [13]. Learners acquire new scientific knowledge and its components like facts, concepts or principles through inquiry or more specifically, inquiry activities [14]. This can be done so by activating the scientific thinking based on the use and activation of cognitive, affective and psychomotor processes. Activities conducted by the learner are called inquiry while concluded outcomes are known as discovery. Thus, the importance of inquiry lies in the fact that it helps improving the learners' scientific thinking abilities through repeating and organizing knowledge, generating ideas, making conclusions and applying it in realistic contexts.

The main topic of education reform, in general and more specifically, the reform movement based on the US National Science Standards was centered on what and how to teach students the science materials. The reform movement supposed that concentration in teaching science should be on helping students acquire and implement skills and activities of exploration and inquiry. Moreover, concentration should be on helping learners look for knowledge and build it by themselves. Consequently, it will allow curriculum to involve the basic scientific ideas in the scientific knowledge [25]. Discovery and inquiry provide learners with the ability to search and build knowledge by themselves. They increase students' scientific achievement and help them acquire life and practical skills necessary for dealing with problems they may encounter in future. Moreover, they make them projects of scientists in future and will accelerate the nation's progress towards development. On the other part, success of the teacher in teaching science depends on his ability to plan and implement inquiry activities. The teacher, who is scientifically well qualified, is capable of achieving the desired goals. In brief, goals of education reform will not be achieved despite the effort spent on doing so if the teacher is worried by social status and poor qualification [15].

In brief, inquiry is one of the most important models of teaching that enables the teacher to acquire skills of thinking [16] and develop the desired scientific attitudes [17]. Teachers' attitudes towards scientific inquiry largely affect their classroom practices and consequently determine the inquiry practice degrees of their students and influence their skills and attitudes towards science [1]. Furthermore, the teacher's acquisition of scientific inquiry skills is one factor that, in turn, helps students acquire these skills. Science teachers' acquisition of scientific inquiry skills empowers them to use effectively these skills while teaching science, which will be reflected on their students' levels if they are trained on such skills [18].

\subsection{Statement of the Problem}

Interest in professional development of science and mathematics in-service teachers has increased after the emergence of science and mathematics curricula. This interest drives teachers to update their skills to meet the requirements of these curricula. Although McGraw-Hill series, whether original or Arabicized, were developed according to the scientific inquiry approach. However, implemented programs to professionally develop teachers to cope with these new curricula did not yield the desired change in their educational practices $[19,20]$. The process of developing science and mathematics teacher can be feasible and effective if all scientific and educational aspects are included via different resources that enrich the process of teacher development [21]. Quality of science and mathematics teaching and learning depends mainly on the teachers' quality and efficiency [22]. Among the teachers' educational needs identified by a research conducted by the Research Excellence Center (REC) was the need to understand the method of scientific inquiry and its uses in teaching science. Thus, the present study is one of the studies adopted by the RCE within the professional development research series, which was considered among the important research priorities in the field of practical education from the viewpoints of specialists in Saudi Arabia [23]. Moreover, findings of the present study may help stakeholders to pay more attention to such professional development programs to ensure their quality in future [21,24]. Inquiry-based teaching methods are of great importance. Educational studies and theories have stressed the role of inquiry in teaching science to develop learners' skills and understanding of science, scientific abilities, and attitudes. Therefore, inquiry was adopted by most educational systems. It represents the most important part of the US National Standards that is currently used as a main criterion in the development of science curricula and methods of teaching worldwide. 
In Saudi Arabia, new inquiry-based curricula have been developed as part of education reform [25,26]. Therefore, the present study aims to identify the extent to which science teachers understand and practice the scientific inquiry in teaching science at schools in Saudi Arabia.

\subsection{Importance of the Study}

The study is believed to be important because it addresses inquiry as the main key for successful learning and teaching process. By inquiry, learners go along the same way that scientists do and can acquire the skills of science and scientific research. Inquiry-based sciences generate scientific culture, knowledge of scientific methods and terms, understanding of concepts and positive attitudes $[5,10]$. Besides, the present study is important because of the reasons below:

1. It addresses inquiry, whose targeting during science teaching, is one of the most important orientations in teaching science in general.

2. It concentrates on science teachers at primary and secondary stages who can gain help to deal with science textbooks that are newly adopted in Saudi schools. In addition, it can contribute to the development of those teachers' practices in future that can be reflected to learners' skills later on.

3. Specialists in teacher preparation and professional development programs may benefit from the present study and develop it to ensure that science teachers can acquire and apply science inquiry skills in their science classes.

\subsection{Study Questions}

In light of the justifications mentioned in the statement of the problem, the present study aims to answer these questions.

1. To what extent do teachers of science practice inquiry-based teaching methods?

2. To what extent do teachers of science engage their students in inquiry activities?

3. Do the extents to which science teachers practice inquiry-based teaching methods and engage their students in the inquiry-based activities vary in accordance to gender?

4. Do the extents to which science teachers practice inquiry-based teaching methods and engage their students in the inquiry-based activities vary in accordance to teaching experience?

\subsection{Study Aims}

The present study aims to:

1. Identify to which extent teachers of science practice inquiry-based teaching methods.

2. Identify to which extent teachers of science engage students in inquiry-based activities.

3. Identify the nature of teachers' classroom activities besides the relationship between their practices and understanding of scientific inquiry.

4. Identify the impact of gender and experience on teachers' inquiry-based teaching practices and the engagement of students in inquiry activities.

\section{Methodology}

\subsection{Study Approach}

The descriptive and analytical approach was used to answer the study questions.

\subsection{Study Population and Sample}

Population of the present study consisted of all science teachers at the intermediate stage at Najran region at Saudi Arabia. The study sample consisted of (156) participant teachers among which were (84) males and (72) females. All of them were chosen by the use of cluster sampling method. Table 1 shows participants' distribution to study variables, i.e. gender, experience and specialty.

Table 1 reveals that about (42\%) of male participant teachers were of long experience, $(19 \%)$ were of moderate experience and (39\%) were of short experience. On the other hand, only (25\%) of female participants were of long experience, (20\%) of moderate experience and (55\%) of short experience. This variance can be interpreted by the fact that most Saudi females, as well as females in most Arab countries, retire at early age or join the teaching profession at late age unlike males who stay longer times in their professions.

Table 1. Distribution of study sample to study variables

\begin{tabular}{|c|c|c|c|c|c|c|c|}
\hline \multirow[b]{3}{*}{ Experience } & \multicolumn{7}{|c|}{ Gender } \\
\hline & \multicolumn{3}{|c|}{ Male } & \multicolumn{3}{|c|}{ Female } & \multirow[b]{2}{*}{ Total } \\
\hline & $\frac{\text { 믐 }}{\text { 음 }}$ & 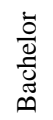 & 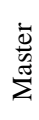 & $\frac{\stackrel{ }{\Xi}}{\stackrel{0}{\circ}}$ & $\begin{array}{l}\tilde{0} \\
\frac{\tilde{D}}{\tilde{D}} \\
\tilde{D} \\
0\end{array}$ & 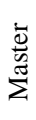 & \\
\hline Long & 1 & 31 & 4 & 6 & 12 & 0 & 54 \\
\hline Moderate & 1 & 15 & 0 & 1 & 12 & 1 & 30 \\
\hline Short & 0 & 28 & 5 & 3 & 36 & 0 & 72 \\
\hline Total & 1 & 74 & 9 & 10 & 60 & 1 & 156 \\
\hline
\end{tabular}

\subsection{Study Instrument}

The questionnaire, in light of the nature of the data to be collected; the study approach; allotted time and the physical potentials, was believed to be the most appropriate tool in the present study. Thus, a questionnaire of two main parts was developed to collect data and was then administered to all participant teachers in the present study. The first part included the personal information of each respondent. The second part included two main fields. The first one was to check the extent to which teachers practice inquiry-based method and consisted of two items. The second one aimed to identify to what extent teachers engage their students in inquiry-based activities at classroom and involved (21) items. Likert's scale was used and five responses were attached to each statement namely "Each class", "Sometimes a week", "Once a week", "Two/three times a month", "Once a month", and "Do not use it at all". Then degrees like (5, 4, 3, 2, 1, \& 0 ) were assigned to these responses respectively. Practice degrees were determined in accordance to this formula:

Category length= [highest degree (6)-lowest degree (0)] $\div$ Number of responses $(6)=(0.83)$ 
Therefore, practice degrees that ranged from "0-below than 0.83", "0.83-below than 1.66", "1.66-below than 2.49", "2.49-below than 3.32", "3.32-below than 4.15" and "4.15-5.00" represented responses like, "each class", "sometimes a week", "once a week", "two or three times a month", "once a month", and " not use it at all" respectively.

\subsection{Validity of the Study Instrument}

The preliminary version of the questionnaire was presented to a number of arbitrators who were specialists in the field of mathematics teaching. Modifications were made according to their viewpoints. In addition, internal consistency values between each item and the field to which it belongs were extracted based on the actual application data of the questionnaire. Values showed a statistical significance at $(\alpha=0.01)$ for the correlation between each item and its field. Strength of correlation was ranging between medium and strong. Table 2 presents the internal consistency of all items and fields.

Table 2. Pearson Correlation coefficients between questionnaire items and fields

\begin{tabular}{|c|c|c|}
\hline Study field & Items & Correlation coefficients \\
\hline \multirow{2}{*}{$\begin{array}{l}\text { 1. Use of inquiry-based } \\
\text { teaching methods }\end{array}$} & 1 & $0.877 * *$ \\
\hline & 2 & $0.859^{* *}$ \\
\hline \multirow{20}{*}{$\begin{array}{l}\text { 2. Engagement of students in } \\
\text { inquiry-based activities }\end{array}$} & 1 & $0.750 * *$ \\
\hline & 2 & $0.718^{* *}$ \\
\hline & 3 & $0.655^{* *}$ \\
\hline & 4 & $0.640 * *$ \\
\hline & 5 & $0790 * *$ \\
\hline & 6 & $0.792 * *$ \\
\hline & 7 & $0.644^{* *}$ \\
\hline & 8 & $0.633^{* *}$ \\
\hline & 9 & $0780 * *$ \\
\hline & 10 & $0.795^{* *}$ \\
\hline & 11 & $0.740^{* *}$ \\
\hline & 12 & $0.739 * *$ \\
\hline & 13 & $0.732 * *$ \\
\hline & 14 & $0.755^{* *}$ \\
\hline & 15 & $0.743^{* *}$ \\
\hline & 16 & $0.708^{* *}$ \\
\hline & 17 & $0.732 * *$ \\
\hline & 18 & $0.745^{* *}$ \\
\hline & 19 & $0.742^{* *}$ \\
\hline & 20 & $0.708^{* *}$ \\
\hline
\end{tabular}

$* * \alpha=0.01$.

Results in Table 2 indicate appropriate correlation degrees of all items to the fields they belong to. Despite the fact that these coefficients do not assert directly that items of each field check what they are assumed to do, they, besides the arbitrators' judgement, ensure that items of each field measure what they are assumed to do.

\subsection{Reliability of the Questionnaire}

To check the questionnaire's reliability, internal consistency was calculated by applying it to a pilot sample who were not involved in the main study sample. Cronbach alpha was used for this sake. Table (3) presents the extracted coefficients.

Table 3. Coefficients of Cronbach Alpha for the entire questionnaire and for its fields

\begin{tabular}{lc}
\hline Field & $\begin{array}{c}\text { Cronbach Alpha } \\
\text { Coefficients }\end{array}$ \\
\hline $\begin{array}{l}\text { First field: Use of inquiry-based teaching } \\
\text { methods }\end{array}$ & 0.877 \\
$\begin{array}{l}\text { Second field: Engagement of students in inquiry- } \\
\text { based activities }\end{array}$ & 0.788 \\
\hline The entire questionnaire & 0.829 \\
\hline
\end{tabular}

Results in Table 3 prove that reliability coefficients of the entire questionnaire and for its two fields are appropriate for the study and so results are assumed to be trustful.

\section{Study Findings}

\subsection{Findings Related to the First Question}

To answer the first questions that stated "To what extent do teachers of science practice inquiry-based teaching methods?" mean scores and standard deviations for the responses of all participants were extracted. Results are shown in Table 4.

Results in Table 4 reveal that science teachers practice the scientific inquiry based teaching methods several times a week $(M=3.50)$. They believe that it is very important to engage students in inquiry-based activities sometimes a week $(\mathrm{M}=3.82)$.

\subsection{Findings Related to the Second Question}

To answer the second question that stated "To what extent do teachers of science engage their students in inquiry activities?" mean scores and standard deviations for the responses of all participants were extracted. Results are shown in Table 5.

Results in Table 5 reveal that participants' responses, regarding to what extent they engage their students in scientific inquiry-based activities, were ranging between once a week and two or three times a month.

Table 4. Mean scores and standard deviation of participants responses to the use of inquiry-based teaching methods field

\begin{tabular}{lccc}
\hline Items & N. & M. & SD. \\
\hline $\begin{array}{l}\text { 1. To what extent do you engage your students in the inquiry-based teaching } \\
\text { practice during the academic year? }\end{array}$ & 125 & 3.50 & 1.299 \\
$\begin{array}{l}\text { 2. To what extent do you think that your student should be engaged in the } \\
\text { inquiry-based teaching practice during the academic year? }\end{array}$ & 131 & 3.82 & 1.140 \\
\hline
\end{tabular}


Table 5. Mean scores and standard deviation of participants' responses to engagement of students in inquiry-based activities

\begin{tabular}{|c|c|c|c|c|}
\hline Items & N. & M. & SD. & Practice extent \\
\hline 1. Students ask questions about the human-made natural world. & 152 & 3.211 & 1.4265 & Once a week \\
\hline 2. Students make questions that can be tested in the classroom. & 153 & 2.850 & 1.3991 & Once a week \\
\hline $\begin{array}{l}\text { 3. Students ask questions about the characters, patterns and inconsistencies seen in the } \\
\text { data lists. }\end{array}$ & 153 & 2.719 & 1.5996 & Once a week \\
\hline 4. Students design drawings and forms as representations for events and systems. & 153 & 2.693 & 1.6030 & Once a week \\
\hline $\begin{array}{l}\text { 5. Students represent and interpret phenomena by multiple models such as drawing } \\
\text { particles with links or making three- dimension models. }\end{array}$ & 153 & 2.693 & 1.6830 & Once a week \\
\hline 6. Students discuss limitations, constraints and accuracy of models. & 153 & 2.340 & 1.7516 & Two/three times a month \\
\hline $\begin{array}{l}\text { 7. Students decide what data to be collected, what tools to collect them and how } \\
\text { measurements are recorded. }\end{array}$ & 153 & 2.471 & 1.7093 & Two/three times a month \\
\hline $\begin{array}{l}\text { 8. Students decide the amount of data required to produce reliable measurements taking } \\
\text { into account the constraints and accuracy. }\end{array}$ & 151 & 1.172 & 1.7040 & Once a week \\
\hline $\begin{array}{l}\text { 9. Students plan for practical experiments indicating independent and dependent variables } \\
\text { besides the procedures to control them. }\end{array}$ & 153 & 2.399 & 1.6676 & Two/three times a month \\
\hline $\begin{array}{l}\text { 10. Students analyze data in a systematic manner and check whether data is consistent } \\
\text { with declared hypotheses. }\end{array}$ & 152 & 2.434 & 1.6625 & Two/three times a month \\
\hline $\begin{array}{l}\text { 11. Students use suitable charts, tables, figures, graphs, statistics, and calculations to } \\
\text { collect, summarize, and present data for the purpose of discovering relationships between } \\
\text { variables. }\end{array}$ & 152 & 2.033 & 1.6575 & Two/three times a month \\
\hline $\begin{array}{l}\text { 12. Students evaluate the strength of conclusions derived from any sum of data using } \\
\text { appropriate calculations and techniques. }\end{array}$ & 152 & 2.000 & 1.6518 & Two/three times a month \\
\hline $\begin{array}{l}\text { 13. Students build their own interpretations for the phenomena using their knowledge of } \\
\text { scientifically agreed theories and associate them with models and evidence. }\end{array}$ & 153 & 2.261 & 1.6534 & Two/three times a month \\
\hline $\begin{array}{l}\text { 14. Students use scientific evidence and models to support or reject the explanatory } \\
\text { explanation of the phenomenon. }\end{array}$ & 153 & 2.261 & 1.6811 & Two/three times a month \\
\hline 15. Students identify potential weaknesses of explanatory explanations. & 152 & 2.059 & 1.6366 & Two/three times a month \\
\hline 16. Students build their own argument and explain how the data support their claims. & 153 & 1.098 & 1.7463 & Two/three times a month \\
\hline $\begin{array}{l}\text { 17. Students identify the potential determinants of scientific arguments appropriate for the } \\
\text { level of students' knowledge and discuss them using reasoning and evidence. }\end{array}$ & 153 & 2.007 & 1.6682 & Two/three times a month \\
\hline $\begin{array}{l}\text { 18. Students understand that characteristics of scientific controversies are allegations, data } \\
\text { and reasons, and they distinguish them by examples. }\end{array}$ & 152 & 2.013 & 1.6316 & Two/three times a month \\
\hline $\begin{array}{l}\text { 19. Students use words, tables, and graphics to communicate or ask questions about a } \\
\text { certain system under study. }\end{array}$ & 152 & 2.329 & 1.6307 & Two/three times a month \\
\hline $\begin{array}{l}\text { 20. Students read scientific texts appropriate for the grade level on tables and figures, and } \\
\text { they interpret or present concluded ideas. }\end{array}$ & 152 & 2.566 & 1.7289 & Once a week \\
\hline $\begin{array}{l}\text { 21. Students write illustrative and written texts or present orally an explanation of their } \\
\text { ideas. }\end{array}$ & 153 & 2.320 & 1.7269 & Two/three times a month \\
\hline
\end{tabular}

\subsection{Findings Related to the Third Question}

To answer the third question that stated "Do the extents to which science teachers practice inquiry-based teaching methods and engage their students in the inquiry activities vary in accordance to their gender and experience?", mean scores and standard deviations for the responses of male and female teachers were calculated. $\mathrm{T}$. Test was also used to check whether there were any significant differences between the responses of male and female teachers. Results regarding participants' gender are shown in Table 6 and Table 7.

Table 6 reveals no statistically significant differences between the responses of male and female participant teachers with regard to their practice of scientific inquiry-based teaching methods due to their gender. Responses of male and female teachers revealed that they both practice inquiry-based teaching methods sometimes a week.

Table 7 indicates no statistically significant differences between male and female teachers regarding the engagement of their students in practicing most of the scientific inquiry-based activities. Nevertheless, statistically significant differences were found between male and female teachers in favor of females in accordance to items like:

1. Designing drawings and forms as representations for events and systems.

2. Representing and interpreting phenomena by multiple models such as drawing, particles with links or making three- dimension models.

3. Deciding what data to be collected and tools to be used.

4. How measurements are recorded.

Table 6. Responses of participant teachers to the use of inquiry-based teaching methods

\begin{tabular}{|c|c|c|c|c|c|c|c|}
\hline Field items & Gender & N. & M. & SD & T. value & DF & Sig. \\
\hline \multirow{2}{*}{$\begin{array}{l}\text { 1. To what extent do you enroll your students in the } \\
\text { inquiry-based teaching practice during the academic year? }\end{array}$} & Male & 64 & 3.44 & 1.283 & \multirow{2}{*}{-0.481} & \multirow{2}{*}{122} & \multirow{2}{*}{0.631} \\
\hline & Female & 60 & 3.55 & 1.320 & & & \\
\hline \multirow{2}{*}{$\begin{array}{l}\text { 2. To what extent do you think that your student should be } \\
\text { engaged in the inquiry-based teaching practice during the } \\
\text { academic year? }\end{array}$} & Male & 69 & 3.81 & 1.061 & \multirow{2}{*}{-0.040} & \multirow{2}{*}{128} & \multirow{2}{*}{0.968} \\
\hline & Female & 61 & 3.82 & 1.232 & & & \\
\hline
\end{tabular}


Table 7. Responses of male and female teachers to the engagement of students in inquiry-based activities

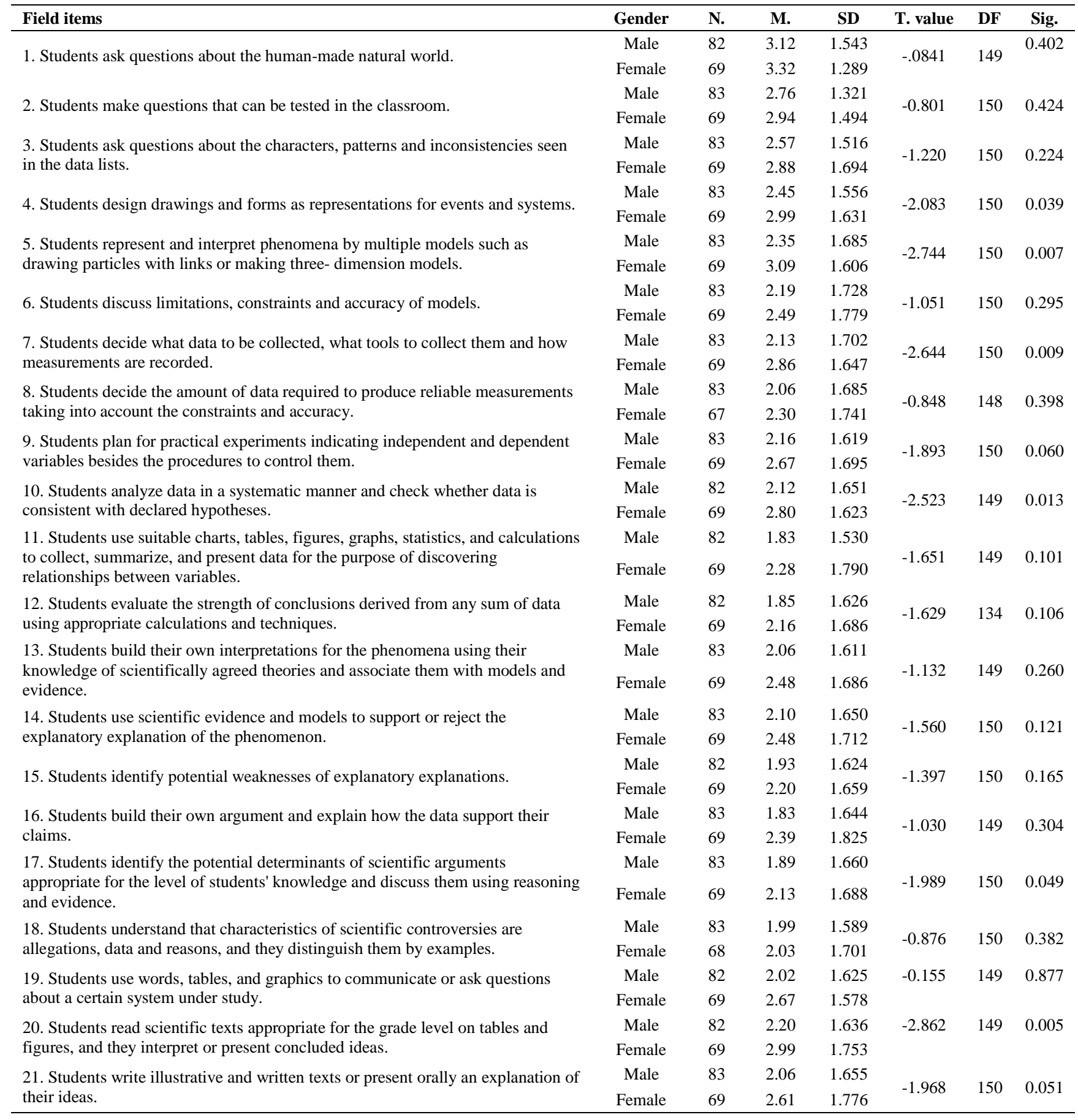

Table 8. T. test for the differences between participants responses to the "use of inquiry-based teaching methods field

\begin{tabular}{|c|c|c|c|c|}
\hline Field items & Experience & $\mathrm{N}$. & M. & SD \\
\hline \multirow{4}{*}{$\begin{array}{l}\text { 1. To what extent do you engage your students in inquiry-based teaching practice during the } \\
\text { academic year? }\end{array}$} & long & 55 & 3.36 & 1.406 \\
\hline & Moderate & 26 & 3.38 & 1.444 \\
\hline & Short & 44 & 3.75 & 1.037 \\
\hline & Total & 125 & 3.50 & 1.299 \\
\hline \multirow{4}{*}{$\begin{array}{l}\text { 2. To what extent do you think that your student should be engaged in the inquiry-based } \\
\text { teaching practice during the academic year? }\end{array}$} & long & 58 & 3.93 & 1.183 \\
\hline & Moderate & 24 & 3.79 & 1.351 \\
\hline & Short & 49 & 3.71 & .979 \\
\hline & Total & 131 & 3.82 & 1.140 \\
\hline
\end{tabular}

\subsection{Findings Related to the Third Question}

With regard to whether there were significant differences between participants' responses that can be due to experience, T. test and ANOVA were used. Results are presented in Table 8 and Table 9.

Table 8 and Table 9 indicate that there were differences between participants' responses to both study fields due to 
experience. Nevertheless, these differences were difficult to judge in favor of which type of experience whether long, moderate or short. Therefore, ANOVA was used. Table 10 and Table 11 show the results.

Table 9. T. test for the differences between participants responses to the engagement of students in inquiry-based activities

\begin{tabular}{|c|c|c|c|c|}
\hline Field items & Experience & N. & M. & SD \\
\hline \multirow{4}{*}{ 1. Students ask questions about the human-made natural world. } & long & 70 & 3.114 & 1.4600 \\
\hline & Moderate & 28 & 3.607 & 1.1969 \\
\hline & Short & 54 & 3.130 & 1.4800 \\
\hline & Total & 152 & 3.211 & 1.4265 \\
\hline \multirow{3}{*}{ 2. Students make questions that can be tested in the classroom. } & long & 70 & 2.729 & 1.4236 \\
\hline & Moderate & 28 & 3.143 & 1.5327 \\
\hline & Total & 153 & 2.850 & 1.3991 \\
\hline \multirow{4}{*}{$\begin{array}{l}\text { 3. Students ask questions about the characters, patterns and inconsistencies } \\
\text { seen in the data lists. }\end{array}$} & long & 70 & 2.414 & 1.7236 \\
\hline & Moderate & 28 & 2.857 & 1.6265 \\
\hline & Short & 55 & 3.036 & 1.3603 \\
\hline & Total & 153 & 2.719 & 1.5996 \\
\hline \multirow{3}{*}{$\begin{array}{l}\text { 4. Students design drawings and forms as representations for events and } \\
\text { systems. }\end{array}$} & long & 70 & 2.500 & 1.7425 \\
\hline & Short & 55 & 3.127 & 1.1872 \\
\hline & Total & 153 & 2.693 & 1.6030 \\
\hline \multirow{4}{*}{$\begin{array}{l}\text { 5. Students represent and interpret phenomena by multiple models such as } \\
\text { drawing particles with links or making three- dimension models. }\end{array}$} & long & 70 & 2.543 & 1.7831 \\
\hline & Moderate & 28 & 2.857 & 1.8402 \\
\hline & Short & 55 & 2.800 & 1.4707 \\
\hline & Total & 153 & 2.693 & 1.6830 \\
\hline \multirow{4}{*}{ 6. Students discuss limitations, constraints and accuracy of models. } & long & 70 & 1.943 & 1.8248 \\
\hline & Moderate & 28 & 2.679 & 1.6567 \\
\hline & Short & 55 & 2.673 & 1.6222 \\
\hline & Total & 153 & 2.340 & 1.7516 \\
\hline \multirow{3}{*}{$\begin{array}{l}\text { 7. Students decide what data to be collected, what tools to collect them and } \\
\text { how measurements are recorded. }\end{array}$} & long & 70 & 2.271 & 1.8644 \\
\hline & Moderate & 28 & 2.536 & 1.5749 \\
\hline & Short & 55 & 2.691 & 1.5620 \\
\hline \multirow{3}{*}{$\begin{array}{l}\text { 8. Students decide the amount of data required to produce reliable } \\
\text { measurements taking into account the constraints and accuracy. }\end{array}$} & Moderate & 28 & 2.179 & 1.5647 \\
\hline & Short & 55 & 2.527 & 1.6539 \\
\hline & Total & 151 & 2.172 & 1.7040 \\
\hline \multirow{4}{*}{$\begin{array}{l}\text { 9. Students plan for practical experiments indicating independent and } \\
\text { dependent variables besides the procedures to control them. }\end{array}$} & long & 70 & 2.114 & 1.7573 \\
\hline & Moderate & 28 & 2.429 & 1.4511 \\
\hline & Short & 55 & 2.745 & 1.6127 \\
\hline & Total & 153 & 2.399 & 1.6676 \\
\hline \multirow{4}{*}{$\begin{array}{l}\text { 10. Students analyze data in a systematic manner and check whether data is } \\
\text { consistent with declared hypotheses. }\end{array}$} & long & 70 & 2.300 & 1.7722 \\
\hline & Moderate & 28 & 2.536 & 1.3467 \\
\hline & Short & 54 & 2.556 & 1.6786 \\
\hline & Total & 152 & 2.434 & 1.6625 \\
\hline \multirow{4}{*}{$\begin{array}{l}\text { 11. Students use suitable charts, tables, figures, graphs, statistics, and } \\
\text { calculations to collect, summarize, and present data for the purpose of } \\
\text { discovering relationships between variables. }\end{array}$} & long & 70 & 1.900 & 1.7541 \\
\hline & Moderate & 28 & 2.357 & 1.5685 \\
\hline & Short & 54 & 2.037 & 1.5777 \\
\hline & Total & 152 & 2.033 & 1.6575 \\
\hline \multirow{4}{*}{$\begin{array}{l}\text { 12. Students evaluate the strength of conclusions derived from any sum of } \\
\text { data using appropriate calculations and techniques. }\end{array}$} & long & 70 & 1.814 & 1.6267 \\
\hline & Moderate & 27 & 2.185 & 1.7105 \\
\hline & Short & 55 & 2.145 & 1.6602 \\
\hline & Total & 152 & 2.000 & 1.6518 \\
\hline \multirow{4}{*}{$\begin{array}{l}\text { 13. Students build their own interpretations for the phenomena using their } \\
\text { knowledge of scientifically agreed theories and associate them with models } \\
\text { and evidence. }\end{array}$} & long & 70 & 2.143 & 1.7552 \\
\hline & Moderate & 28 & 2.143 & 1.6036 \\
\hline & Short & 55 & 2.473 & 1.5498 \\
\hline & Total & 153 & 2.261 & 1.6534 \\
\hline \multirow{3}{*}{$\begin{array}{l}\text { 14. Students use scientific evidence and models to support or reject the } \\
\text { explanatory explanation of the phenomenon. }\end{array}$} & long & 70 & 2.057 & 1.7353 \\
\hline & Moderate & 28 & 2.179 & 1.7858 \\
\hline & Short & 55 & 2.564 & 1.5368 \\
\hline
\end{tabular}




\begin{tabular}{|c|c|c|c|c|}
\hline Field items & Experience & N. & M. & SD \\
\hline \multirow{4}{*}{ 15. Students identify potential weaknesses of explanatory explanations. } & long & 70 & 1.800 & 1.7076 \\
\hline & Moderate & 28 & 1.964 & 1.7317 \\
\hline & Short & 54 & 2.444 & 1.4363 \\
\hline & Total & 152 & 2.059 & 1.6366 \\
\hline \multirow{3}{*}{$\begin{array}{l}\text { 16. Students build their own argument and explain how the data support } \\
\text { their claims. }\end{array}$} & long & 70 & 2.043 & 1.8450 \\
\hline & Moderate & 28 & 2.107 & 1.6852 \\
\hline & Total & 153 & 2.098 & 1.7463 \\
\hline \multirow{4}{*}{$\begin{array}{l}\text { 17. Students identify the potential determinants of scientific arguments } \\
\text { appropriate for the level of students' knowledge and discuss them using } \\
\text { reasoning and evidence. }\end{array}$} & long & 70 & 1.986 & 1.7486 \\
\hline & Moderate & 28 & 1.571 & 1.4764 \\
\hline & Short & 55 & 2.255 & 1.6355 \\
\hline & Total & 153 & 2.007 & 1.6682 \\
\hline \multirow{3}{*}{$\begin{array}{l}\text { 18. Students understand that characteristics of scientific controversies are } \\
\text { allegations, data and reasons, and they distinguish them by examples. }\end{array}$} & long & 70 & 1.871 & 1.6933 \\
\hline & Moderate & 28 & 1.893 & 1.4991 \\
\hline & Total & 152 & 2.013 & 1.6316 \\
\hline \multirow{4}{*}{$\begin{array}{l}\text { 19. Students use words, tables, and graphics to communicate or ask } \\
\text { questions about a certain system under study. }\end{array}$} & long & 70 & 2.143 & 1.7049 \\
\hline & Moderate & 27 & 2.667 & 1.5689 \\
\hline & Short & 55 & 2.400 & 1.5587 \\
\hline & Total & 152 & 2.329 & 1.6307 \\
\hline \multirow{4}{*}{$\begin{array}{l}\text { 20. Students read scientific texts appropriate for the grade level on tables } \\
\text { and figures, and they interpret or present concluded ideas. }\end{array}$} & long & 70 & 2.414 & 1.7815 \\
\hline & Moderate & 28 & 2.821 & 1.8470 \\
\hline & Short & 54 & 2.630 & 1.6054 \\
\hline & Total & 152 & 2.566 & 1.7289 \\
\hline \multirow{4}{*}{$\begin{array}{l}\text { 21. Students write illustrative and written texts or present orally an } \\
\text { explanation of their ideas. }\end{array}$} & long & 70 & 2.071 & 1.7472 \\
\hline & Moderate & 28 & 2.464 & 1.7739 \\
\hline & Short & 55 & 2.564 & 1.6640 \\
\hline & Total & 153 & 2.320 & 1.7269 \\
\hline
\end{tabular}

Table 10. ANOVA for the differences in the mean scores of participants' responses to the use of inquiry-based teaching methods due to experience

\begin{tabular}{|c|c|c|c|c|c|c|}
\hline Use of inquiry-based teaching methods & Source of variation & Sum of squares & DF & Mean of means & F. value & Sig. \\
\hline \multirow{3}{*}{$\begin{array}{l}\text { 1. To what extent do you enroll your students } \\
\text { in the inquiry-based teaching practice during } \\
\text { the academic year? }\end{array}$} & Between groups & 4.117 & 2 & 2.058 & \multirow{3}{*}{1.224} & \multirow{3}{*}{0.298} \\
\hline & Within groups & 205.131 & 122 & \multirow{2}{*}{1.681} & & \\
\hline & Total & 209.248 & 124 & & & \\
\hline \multirow{3}{*}{$\begin{array}{l}\text { 2. To what extent do you think that your } \\
\text { student should be engaged in the inquiry-based } \\
\text { teaching practice during the academic year? }\end{array}$} & Between groups & 1.279 & 2 & 0.640 & \multirow{3}{*}{0.488} & \multirow{3}{*}{0.615} \\
\hline & Within groups & 167.682 & 128 & 1.310 & & \\
\hline & Total & 168.962 & 130 & & & \\
\hline
\end{tabular}

Table 11. ANOVA for the differences in the mean scores of participants' responses to engagement of students in inquiry-based activities field due to experience

\begin{tabular}{|c|c|c|c|c|c|c|}
\hline Engagement of students in inquiry-based activities & Source of variation & Sum of squares & DF & Mean of means & F. value & Sig. \\
\hline \multirow{3}{*}{$\begin{array}{l}\text { 1. Students ask questions about the human-made } \\
\text { natural world. }\end{array}$} & Between groups & 5.406 & 2 & 2.703 & \multirow{3}{*}{1.334} & \multirow{3}{*}{0.266} \\
\hline & Within groups & 301.857 & 149 & \multirow{2}{*}{2.026} & & \\
\hline & Total & 307.263 & 151 & & & \\
\hline \multirow{3}{*}{$\begin{array}{l}\text { 2. Students make questions that can be tested in the } \\
\text { classroom. }\end{array}$} & Between groups & 3.435 & 2 & 1.717 & \multirow{3}{*}{0.876} & \multirow{3}{*}{0.419} \\
\hline & Within groups & 294.108 & 150 & \multirow{2}{*}{1.961} & & \\
\hline & Total & 297.542 & 152 & & & \\
\hline \multirow{3}{*}{$\begin{array}{l}\text { 3. Students ask questions about the characters, patterns } \\
\text { and inconsistencies seen in the data lists. }\end{array}$} & Between groups & 12.573 & 2 & 6.287 & \multirow{3}{*}{2.506} & \multirow{3}{*}{0.085} \\
\hline & Within groups & 376.342 & 150 & \multirow{2}{*}{2.509} & & \\
\hline & Total & 388.915 & 152 & & & \\
\hline \multirow{3}{*}{$\begin{array}{l}\text { 4. Students design drawings and forms as } \\
\text { representations for events and systems. }\end{array}$} & Between groups & 16.846 & 2 & 8.423 & \multirow{3}{*}{3.381} & \multirow{3}{*}{0.037} \\
\hline & Within groups & 373.716 & 150 & \multirow{2}{*}{2.491} & & \\
\hline & Total & 390.562 & 152 & & & \\
\hline \multirow{3}{*}{$\begin{array}{l}\text { 5. Students represent and interpret phenomena by } \\
\text { multiple models such as drawing particles with links or } \\
\text { making three- dimension models. }\end{array}$} & Between groups & 2.962 & 2 & 1.481 & \multirow{3}{*}{0.520} & \multirow{3}{*}{0.596} \\
\hline & Within groups & 427.600 & 150 & \multirow{2}{*}{2.851} & & \\
\hline & Total & 430.562 & 152 & & & \\
\hline \multirow{3}{*}{$\begin{array}{l}\text { 6. Students discuss limitations, constraints and } \\
\text { accuracy of models. }\end{array}$} & Between groups & 20.339 & 2 & 10.170 & \multirow{3}{*}{3.420} & \multirow{3}{*}{0.035} \\
\hline & Within groups & 445.988 & 150 & \multirow{2}{*}{2.973} & & \\
\hline & Total & 466.327 & 152 & & & \\
\hline
\end{tabular}




\begin{tabular}{|c|c|c|c|c|c|c|}
\hline Engagement of students in inquiry-based activities & Source of variation & Sum of squares & DF & Mean of means & F. value & Sig. \\
\hline \multirow{3}{*}{$\begin{array}{l}\text { 7. Students decide what data to be collected, what tools } \\
\text { to collect them and how measurements are recorded. }\end{array}$} & Between groups & 5.565 & 2 & 2.783 & \multirow{3}{*}{0.952} & \multirow{3}{*}{0.388} \\
\hline & Within groups & 438.553 & 150 & \multirow{2}{*}{2.924} & & \\
\hline & Total & 444.118 & 152 & & & \\
\hline \multirow{3}{*}{$\begin{array}{l}\text { 8. Students decide the amount of data required to make } \\
\text { reliable measurements taking into account the } \\
\text { constraints and accuracy. }\end{array}$} & Between groups & 12.648 & 2 & 6.324 & \multirow{3}{*}{2.213} & \multirow{3}{*}{0.113} \\
\hline & Within groups & 422.875 & 148 & \multirow{2}{*}{2.857} & & \\
\hline & Total & 435.523 & 150 & & & \\
\hline \multirow{3}{*}{$\begin{array}{l}\text { 9. Students plan for practical experiments indicating } \\
\text { independent and dependent variables besides the } \\
\text { procedures to control them. }\end{array}$} & Between groups & 12.301 & 2 & 6.150 & \multirow{3}{*}{2.248} & \multirow{3}{*}{0.109} \\
\hline & Within groups & 410.379 & 150 & \multirow{2}{*}{2.736} & & \\
\hline & Total & 422.680 & 152 & & & \\
\hline \multirow{3}{*}{$\begin{array}{l}\text { 10. Students analyze data in a systematic manner and } \\
\text { check whether data is consistent with declared } \\
\text { hypotheses. }\end{array}$} & Between groups & 2.344 & 2 & 1.172 & \multirow{3}{*}{0.421} & \multirow{3}{*}{0.657} \\
\hline & Within groups & 414.998 & 149 & 2785 & & \\
\hline & Total & 417.342 & 151 & 2.185 & & \\
\hline \multirow{2}{*}{$\begin{array}{l}\text { 11. Students use suitable charts, tables, figures, graphs, } \\
\text { statistics, and calculations to collect, summarize, and } \\
\text { present data for the purpose of discovering } \\
\text { relationships between variables. }\end{array}$} & Within groups & 410.654 & 149 & 2756 & \multirow[t]{2}{*}{0.759} & \multirow[t]{2}{*}{0.470} \\
\hline & Total & 414.836 & 151 & 2.156 & & \\
\hline \multirow{3}{*}{$\begin{array}{l}\text { 12. Students evaluate the strength of conclusions } \\
\text { derived from any sum of data using appropriate } \\
\text { calculations and techniques. }\end{array}$} & Between groups & 4.504 & 2 & 2.252 & \multirow{3}{*}{0.823} & \multirow{3}{*}{0.441} \\
\hline & Within groups & 407.496 & 149 & & & \\
\hline & Total & 412.000 & 151 & 2.735 & & \\
\hline \multirow{3}{*}{$\begin{array}{l}\text { 13. Students build their own interpretations for the } \\
\text { phenomena using their knowledge of scientifically } \\
\text { agreed theories and associate them with models and } \\
\text { evidence. }\end{array}$} & Between groups & 3.833 & 2 & 1.917 & \multirow{3}{*}{0.698} & \\
\hline & Within groups & 411.709 & 150 & & & 0.499 \\
\hline & Total & 415.542 & 152 & 2.145 & & \\
\hline 14. Students use scientific evidence and models to & Between groups & 8.137 & 2 & 4.068 & & \\
\hline support or reject the explanatory explanation of the & Within groups & 421.406 & 150 & 2809 & 1.448 & 0.238 \\
\hline phenomenon. & Total & 429.542 & 152 & 2.809 & & \\
\hline & Between groups & 12.969 & 2 & 6.485 & & \\
\hline & Between groups & .452 & 2 & .226 & & \\
\hline $\begin{array}{l}\text { 16. Students build their own argument and explain how } \\
\text { the data support their claims. }\end{array}$ & Within groups & 463.077 & 150 & 3087 & 0.073 & 0.929 \\
\hline & Total & 463.529 & 152 & $3.08 /$ & & \\
\hline 17. Students identify the potential determinants of & Between groups & 8.714 & 2 & 4.357 & & \\
\hline $\begin{array}{l}\text { scientific arguments appropriate for the level of } \\
\text { students' knowledge and discuss them using reasoning }\end{array}$ & Within groups & 414.279 & 150 & & 1.578 & 0.210 \\
\hline and evidence. & Total & 422.993 & 152 & 2.762 & & \\
\hline 18. Students understand that characteristics of scientific & Between groups & 5.082 & 2 & 2.541 & & \\
\hline controversies are allegations, data and reasons, and & Within groups & 396.892 & 149 & & 0.954 & 0.388 \\
\hline they distinguish them by examples. & Total & 401.974 & 151 & 2.664 & & \\
\hline 19. Students use words, tables, and graphics to & Between groups & 5.781 & 2 & 2.891 & & \\
\hline communicate or ask questions about a certain system & Within groups & 395.771 & 149 & 2656 & 1.088 & 0.339 \\
\hline under study. & Total & 401.553 & 151 & 2.656 & & \\
\hline 20. Students read scientific texts appropriate for the & Between groups & 3.657 & 2 & 1.828 & & \\
\hline grade level on tables and figures, and they interpret or & Within groups & 447.685 & 149 & 3005 & 0.609 & 0.546 \\
\hline present concluded ideas. & Total & 451.342 & 151 & 3.005 & & \\
\hline & Between groups & 8.173 & 2 & 4.086 & & \\
\hline $\begin{array}{l}\text { 21. Students write illustrative and written texts or } \\
\text { present orally an explanation of their ideas. }\end{array}$ & Within groups & 445.134 & 150 & 2060 & 1.377 & 0.256 \\
\hline & Total & 453.307 & 152 & 2.968 & & \\
\hline
\end{tabular}

Results in Table 10 reveal no significant differences among participants in accordance to their responses to the use of inquiry-based teaching methods due to experience.

Results in Table 11 indicate no significant differences among most of participants' responses to the engagement of students in inquiry-based activities. However, significant differences were found with regard to engaging students in activities like "designing drawings and forms as representations for events and systems" and "discussing limitations, constraints and accuracy of models". Differences were in favor of long experience participants.

\section{Discussion of the Results}

The present study aimed to identify the extent to which science teachers at Saudi public schools, and mainly at Najran region, use and engage students in the scientific inquiry-based teaching methods and activities. Findings showed that teachers' practice level of inquiry-based teaching methods was too low. Female teachers' practice level was better than male teachers' practice level. Nevertheless, male and female teachers' practice levels were not convincing and did not approach the desired 
level that science teachers should practice. Findings also did not reveal any significant differences among participants due to their teaching experience. This, of course prove that the low level of participant teachers' practice level of inquiry-based teaching methods was a general phenomenon that is not specific to gender and teaching experience.

In fact, science teachers' practice of scientific inquiry-based methods in classrooms is one of the main factors that can empower learners to acquire the skills of the scientific approach when studying natural phenomena and solve problems, [6]. Science teachers' inquiry-based practice scarcity in classrooms will, for sure, deprive students from practicing the scientific inquiry; from acquiring scientific concepts professionally and consequently be able to develop their scientific skills that science aims to achieve.

Low practice level of teachers' scientific inquiry may be interpreted in light of their attitudes towards this teaching method and its role in science teaching. Their conviction of the futility of such a method can be reflected on the kind of their teaching activities. This finding, to a certain extent, corroborates the findings of [21] that assert the impact of teachers' beliefs about the scientific inquiry that highly affect their teaching performance in classroom. On the other hand, learners' low practice level of scientific inquiry, indicated by participants of the present study, prove that they lack many of the scientific skills included in the goals of science teaching. [21] argues that once students are unable to acquire the science learning required skills, they become incapable of developing the desired attitudes towards learning it and so their science learning will be negatively affected and will not be meaningful.

\section{Conclusion}

Achievement of science teaching goals requires appropriate teaching strategies and methods that ensure the quality of learning. Scientific inquiry is one of these most important and effective strategies that can attain understanding-based and learner-centered learning. It can also allow him to practice the processes of science and behave as scientists do in research and query. Such a strategy can teach a learner to identify the problem, set hypotheses, collect information, experiment and conclude results. Then he feels self-confidence, experience the sense of achievement and develop positive attitudes towards science. Moreover, a learner can achieve fun, excitement and continuity. Therefore, it is important for people in charge of the process of education in Saudi Arabia to feel the need to organize and hold training sessions for science teachers to train them to use scientific inquiry and develop positive attitudes towards it. There should be continuous assessment of science teachers' performance in classroom and their discovery and scientific inquiry-based activities should be reinforced. Moreover, it is very important to always evaluate teacher-preparation programs in light of the nature of science, more specifically the skills of inquiry. Students, on the other, part should be encouraged to practice scientific inquiry through the organization of scientific competitions and the creation of competition spirit among them.

\section{References}

[1] Zaitoun, A. M., (1994). Methods of Teaching Science, (1 $1^{\text {st }}$ edition) Amman, Jordan: Dar Al Shorouq for Publishing and Distribution.

[2] Brown, C. \& Nickerson, S. (2009). Modeling the Collective Enquiry Process in Mathematics Teacher Education. Paper presented at the Annual Meeting of the North American Chapter of the International Group for the Psychology of Mathematics Education. OMNI Hotel, Atlanta, GA.

[3] Giles, B. R. (2008). Narrative Inquiry: A Formative Stop of the Road to Culturally Relevant Practice. Paper presented at the Annual Meeting of the American Association of Colleges for Teacher Education. Hilton New Orleans Riverside, New Orleans. LA.

[4] Polman, J. L. (2000). Designing Project Based Science: Connecting Learners through Guided Inquiry. New York: Teachers College Press, Columbia University.

[5] Haury, D. L. (1993). Teaching Science through Inquiry, ERIC CSMEE Digest, ERIC Document No. ED 359048.

[6] National Research Council, (NRC), (1996). The National Science Education Standards, Washington, D.C., National Academy Press.

[7] Alberts, B. (2000). Some Thoughts of Scientists on Inquiry. In J. Minstrell \& E Van Zee (Eds.). Inquiring into Inquiry Learning and Teaching in Science (pp. 3-13). Washington, DC, American Association for the Advancement Science.

[8] Jackson, D. B. (2010). Exploring the Impact of the Epistemological Beliefs of Science Teachers on Authentic Inquiry: A Multiple Case Study. Paper presented at the Annual Meeting of the Ate Annual Meeting, Hilton, Chicago II.

[9] American Association for the Advancement of Science (AAAS). (1990). Science for All Americans. New York: Oxford University Press.

[10] American Association for the Advancement of Science (AAAS) (1993). Benchmarks for Science Literacy, New York, Oxford University Press.

[11] National Research Council (NRC), (2000). Inquiry and the National Science Education Standards. Washington, DC: National Academy Press.

[12] Lederman, N. G. (1992). Students and Teachers' Conceptions of the Nature of Science: A Review of the Research. Journal of Research in Science Teaching, 29(4), 331-359.

[13] Bainchini, J.A. \& Colburn, A. (2000). Teaching the Nature of Science through Inquiry to Prospective Elementary Teachers: A Tale of two Researchers. Journal of Research in Science Teaching, 37, 177-209.

[14] Ben-David, A., \& Zohar, A. (2009). Contribution of MetaStrategic Knowledge to Scientific Inquiry Learning. International Journal of Science Education, 31(12), 1657-1682.

[15] Harrison, C. (2014). Assessment of Inquiry Skills in the SAILS Project. Science Education International, 25(1), 112-122.

[16] Carin, A. A. (1993). Teaching Science through Discovery. New York: Macmillan Publishing Company.

[17] Ghazi, I. T. (2006). The Impact of Using the Learner's Raising Problems-Based Strategy on the Development of First Secondary Graders Academic Achievement and Modification of their Beliefs about the Study of Physics, Journal of Scientific Education, 1 (9), 131-192.

[18] Harrison, C. (2009). Making Assessment work in Classrooms in Assessing Pupils, in Dillon, J \& Maguire, M. Becoming a Teacher, Buckingham, OUP, pp185-187.

[19] Fishman, B., Marx, R., Best, S., \& Tal, R. (2003). Linking Teacher and Students Learning to Improve Professional Development in Systemic Reform. Teaching \& Teacher Education, 19(6), 643-658.

[20] Horsley, S; Stiles, K.; Mundry, S.; Love, N.; Hewson, P. (2003). Designing Professional Development for Teacher if Science \& Mathematics. CA, Corwin Press.

[21] Gao, S. (2014). The Relationship between Teaching Approaches and Student Science Achievement for Four Racial Groups in US Eighth Grade Classes, Ph.D. Dissertation, The Graduate College, University of Nevada, Las Vegas.

[22] Arokoyu, A. \& Aderonmu, T. (2014). Quality of Science Teaching in Public Secondary Schools in Rivers State: The Journey So Far. British Journal of Education, Society \& Behavioral Science, 4(12): 1737-1749. 
[23] Qablan, A.; Mansour, N.; Alshamrani, S.; Aldahmash, A.; \& Aldahmash, S. (2015). Ensuring Effective Impact of Continuing Professional Development: Saudi Science Teachers' Perspective. Eurasia Journal of Mathematics, Science \& Technology Education, 11(3), 619-631.

[24] Darling-Hammond, L.; Arthur, E; \& Pease, S. (1983). Teacher Evaluation in the Organizational Context: A Review of the Literature, Review of Educational Research, fall 1983.

[25] Al Ghanem, G. S. (1999). Reforming Science Education in Saudi Arabia: A Conceptual Framework for the Design of Coordinated and Thematic Science (CATS) Module for Grades 7-9. An Unpublished Doctoral dissertation. Morgantown: West Virginia University.
[26] Al Abdul Kareem, S. A. (2004). Investigating Science Teachers' Beliefs about Science and Science Teaching: Struggles in Implementing Science Education Reform in Saudi Arabia. An Unpublished Doctoral dissertation. Morgantown: West Virginia University.

[27] Garet, M., Porter, A., Desimone, L. Birman, B., \& Yoon, K. (2001). What Makes Professional Development Effective? Analysis of a National Sample of Teachers. American Education Research Journal, 38(4), 915-945.

[28] Minner, (2009) Inquiry-Based Science Instruction: What Is It and Does It Matter? Results from a Research Synthesis Years 1984 to 2002. Journal of Research in Science Teaching, 47(4), 474-496. 